\title{
A Discourse Analysis of Social Media Voices on Turkey's FATIH Project
}

\author{
Ayşe AYDIN AKKURT, Hakan YILDIRIM, H. Mustafa DÖNMEZ*
}

A Discourse Analysis of Social Media Voices on Turkey's FATIH Project

\section{Abstract}

FATIH project of Turkey is one of the largest educational technology projects in the world that aims to ensure equality in education and to improve technological infrastructure at schools. Ekşi Sözlük, one of the most popular social media platforms in Turkey, has been an important agent in interpreting and reproducing information as a new public sphere. This study aims to explore the topics presented within the discourses in Ekşi Sözlük regarding FATIH project. A total of 307 entries posted between 2010 and 2017 were analyzed using the method of discourse analysis. The results showed that FATIH project has been discussed in public sphere in terms of technological, political-ideological and project design dimensions rather than the educational dimension.

Key Words: FATIH Project, New Media, Discourse Analysis, Network Society
Türkiye'nin FATIH Projesine Iliş̧kin Sosyal Medyada Yer Alan Görüşler Üzerine Bir Söylem Analizi

Özet

Türkiye'nin Eğitimde FATiH projesi, eğitimde eşitliği sağlamayı ve okullarda teknolojik altyapıyı geliştirmeyi amaçlayan dünyanın en geniş çaplı eğitim teknolojisi projelerinden biridir. Türkiye'nin en popüler sosyal medya platformlarından biri olan Ekşi Sözlük, bilgiyi yeni bir kamusal alan olarak yorumlamada ve yeniden üretmede önemli bir etken olmaktadır. Bu çalışma, Ekşi Sözlük FATiH projesi ile ilgili olarak yer alan söylemler içerisindeki konu başlıklarını söylem analizi yöntemiyle incelemeyi amaçlamaktadır. 2010 ve 2017 arasında yayımlanan toplam 307 gönderi, söylem analizi yöntemi kullanılarak analiz edilmiştir. Elde edilen sonuçlar, FATiH projesinin, eğitimsel boyuttan ziyade teknolojik, politik-ideolojik ve proje tasarım boyutları açısından kamusal alanda tartışılığını göstermiştir.

Anahtar Kelimeler: FATiH Projesi, Yeni Medya, Söylem Analizi, Ağ Toplumu

\section{Introduction}

As a result of the extremely rapid development of information and communication technologies (ICT) in the world over the past decade, the speed of dissemination of information has reached an unprecedented pace. Rapid dissemination and sharing of information in parallel with the development of ICT and the formation of a key component in new economies, which are

*Ayşe AYDIN AKKURT, PhD, Ministry of National Education, ayseaydinakkurt@gmail.com, ORCID ID orcid.org/00000002-9267-6862, Hakan YILDIRIM, Instructor, Eskişehir Osmangazi University, Distance Learning Implementation and Research Center, hayildirim@ogu.edu.tr, ORCID ID orcid.org/0000-0002-4693-1287, H. Mustafa DÖNMEZ, PhD, Eskişehir Osmangazi University, Department of Foreign Languages, hmdonmez@ogu.edu.tr, ORCID ID orcid.org/00000002-3062-7010 
Ayşe AYDIN AKKURT | Hakan YILDIRIM | H. Mustafa DÖNMEZ

called information economies of ICT, have turned information into a commodity (an economic good) (Ekici and Yllmaz, 2013). The commodification of information is the transformation of information into a product that can be realized in the market by losing value of use. Due to the commodification of information caused by these rapid changes in the production, distribution and sharing of information, having a voice in producing and distributing information has become important globally and influenced the politics of countries that do not want to lag behind others. All countries are seeking to implement, or already implementing, projects as a result of the efforts to efficiently use the human factor, which will play an active role in the production and distribution of information, and to develop the required policies.

According to a report by the Turkish Statistical Institute (TurkStat) titled "Youth in Statistics 2016", youth aged 15 to 24 years make up 16.3\% of the population in Turkey, the youth unemployment rate increased from 18.5 percent in 2015 to 19.6 percent in 2016 and Turkey currently has the youngest population in European area according to data from the World Bank and Statistical Office of the European Communities (TurkStat, 2016). Turkey is seeking to take measures and initiatives so that this young population as human resource can be equipped with the key skills required in modern work environments and they can make a positive impact to the country's development. In this respect, demographic structure of Turkey and developments in ICT make it inevitable for Turkey to make arrangements in its educational policy. In "Information Society Strategy and Action Plan (2006-2010)", Turkey's vision of transformation into information society is stated as "becoming a country that has a leading role in the production of science and technology, that uses information and technology as an effective tool, that generates added value through information-based decision-making processes, and that is prosperous and successful in global competition". Documents such as Development Plans and Ministry of National Education Strategic Plans (Ministry of Development, 2013; Ministry of Education, 2015) define Turkey's actions towards information society, and these actions focus mostly on education.

The term 'technology' is a combination of the words 'techne' (i.e. craft, skill) and 'logia' (i.e. information). Technique is the knowledge of gaining or manufacturing something as a product whereas technology is more about socialization of this knowledge, that is, this knowledge has social implications, social context and social meaning (Atabek, 2005, p. 63). In the process of transformation into the information society, the goal of technology, by definition is to spread ICT in all areas of life. Towards this end, there have been projects all around the world on the use of ICT. There are ongoing projects in South Korea, Britain, Germany, Turkey, Uganda, Georgia, Austria, Cyprus, Peru and India, and there are completed projects in France, Ukraine, Estonia, Greece, Ireland and Lithuania (Doğan et al., 2016, p.6). In addition to the development of ICT education, countries may adopt different approaches to improve the general level of ICT skills as a part of their educational policies. The emergence of coding after computer literacy has influenced the formation of the foundations of the projects in this area. In the implementation process, it is also important to develop problem-solving skills using the principles of computer science as well as 
acquiring these competencies that are important to the sustainability of the system. To this end, the concept of 'computational thinking', which adopts the use of an algorithmic approach to solve problems, comes to the forefront. One of the notable projects with a computational thinkingbased approach is Taccle3 (García-Peñalvo, 2016, p.1), which is a project of the European Union's Erasmus + KA2 Program.

Many governments attach great importance to the development of digital literacy skills from an early age so that children can not only become consumers as software users but also understand and produce digital language. To achieve this goal, incorporating coding and digital thinking approaches into formal curricula is one of the most striking initiatives. Within the framework of formal education, information infrastructure is established in schools, digital course content is produced, and many countries such as India, Peru and Portugal provide computers to students (Turkish Ministry of Development Information Society Department, 2015). In the light of these developments, Turkey launched FATIH ("Fırsatları Artırma ve Teknolojiyi İyileştirme Hareketi" in Turkish, or 'Movement to Increase Opportunities and Technology' in English) project in 2010 so that students can produce knowledge. Being a large-scale and high-budget project that aims to make fundamental changes in formal education in Turkey, FATIH project is a great breakthrough achieved by the country in the use of ICT. Seeking to integrate ICT into education, the project aims to restructure the formal education system in Turkey. Designed to ensure equality in education, to improve technological infrastructure at schools and to provide every student with quality learning opportunities and content, the project is one of the largest national initiatives launched about the use of technology in education (MNE, 2017). FATIH project finances provision of equipment for the classrooms, delivery of broadband Internet to all classrooms, provision of e-content for courses, integration of teachers into ICT, establishment of web platforms for content development and project implementation support. The key components of FATIH project can be seen in Figure 1 (MNE, 2017):

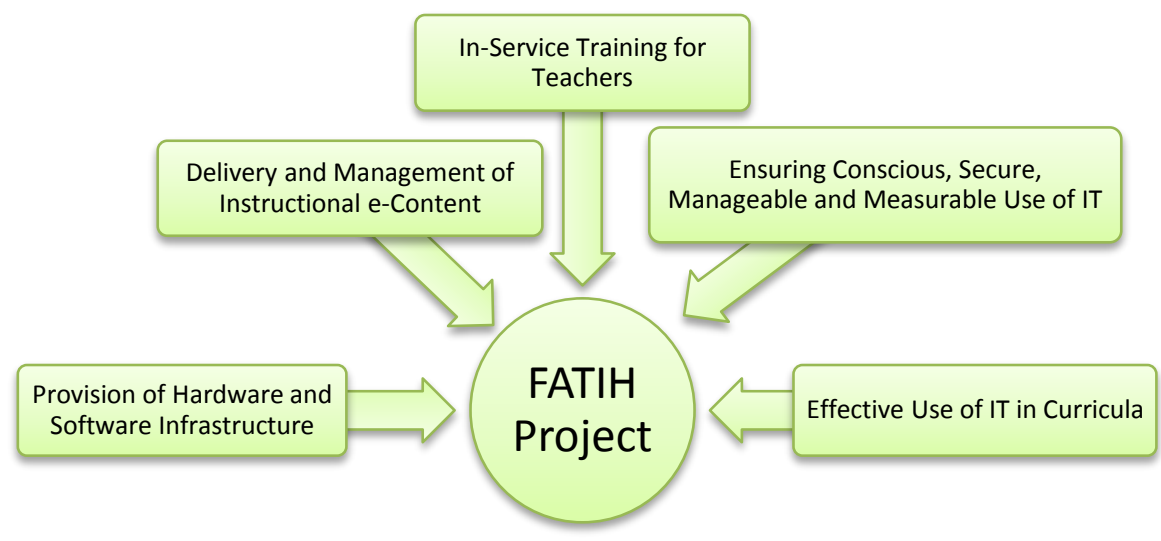

Figure 1. The Key Components of FATIH Project (MNE, 2017) 
It is important in the context of project acceptance and applicability that all stakeholders are active in the process of developing and implementing the project for the sake of the sustainability of a large-scale educational initiative such as FATIH project. Given that Turkey has a large population spread over vast geographical areas across a wide socioeconomic spectrum, the views and participation of the citizens, probably the most important group among the stakeholders, should matter a lot in a project aimed at 'providing equal opportunity'. Doğan et al. $(2016$, p.1) compared FATIH project in Turkey with similar initiatives in other countries, and they found that projects in most countries were launched nationwide without any pilot or feasibility studies and that implementation of the projects lacked cooperation with the stakeholders and involved companies. The environments in which citizens as project stakeholders can express their views on policies are, in the broadest sense, public spheres. In all countries, the poor, the less-educated and working-class citizens are those most affected by state policies, and it is this group of citizens that spend most on their children's education (Demir, 2011, p.8). Today, the Internet is at the forefront of public spheres where citizens can freely express their opinions irrespective of their socio-economic and social status, and can make their voice heard by people who are in the same position as themselves or by policy makers.

Yükselbaba (2008) states that since the publication of "The Structural Transformation of the Public Sphere" by Jürgen Habermas in 1962 introduced the public/private distinction and the public sphere/private sphere distinction, the issue has been discussed by many and new definitions and models of public sphere emerged along with new ideas. It is not the public sphere models that are new in reality, but rather the fact that some phenomena and opinions are viewed and shaped from the perspective of "public sphere". What is meant by the concept of "public sphere", first of all, is an area in social life where something similar to public opinion can be created. Access to this area by all citizens is guaranteed. In each case of private conversations where private individuals are gathered as a public body, a part of the public sphere comes to existence (Yükselbaba, 2008 , p. 250). For Habermas, physical and interpersonal communication is a necessity for the public sphere in order to create a civic space of sharing that can serve as a direct alternative to the state. In this sense, as a sphere for sharing, the Internet has become an important medium where anonymity can be maintained to a large extent and public discussions are held without an agent and regardless of time, place and status.

Habermas's view of the public sphere is compatible with the deliberative democracy theory. Equal and free citizens can publicly deliberate with each other on all kinds of issues. Habermas's public sphere model points to a deepened quest for a democracy and a state of law because there are no restrictions on topics and participation and the public discussion processes must be guaranteed by law (Yükselbaba, 2008, p.267). Habermas defines the public sphere as a social space in which opinions on matters that are important in terms of mutual benefit can be shared and, therefore, public opinion can be formed (Bukan, 2003, p.29). 
Volkmer (2003) and Friedland, Hove and Rojas (2006), who examine Habermas's concept of public sphere in the context of "the Internet" as an intermediary, view the Internet as a public sphere operated by democracy where the political discourse between the ruler and the ruled is circulated. Accompanied by the spread of social networks, communication networks can be expressed as public spheres that trigger transformation and rapid penetration of the ideas of people and institutions, and interaction and modularity. Volkmer (2003, p. 13) states that a new public sphere has been created on a global scale, arguing that new communication technologies have shaped the public sphere. In line with Volkmer's view that a decentralized, censor-neutral and interactive public space has been created, Friedland, Hove and Rojas (2006, pp. 20-21) suggest that the visibility of alternative discourses in the new media has increased in contrast to the traditional media.

There have been different views on the transformation that the Internet and ICT have created in the concept of public sphere. Habermas argues that means of communication have a function that removes the public sphere from within the domain of political and commercial power (Timisi, 2003; p. 15). Communication is a necessity for the formation of the public sphere. Habermas suggests that democratic politics or planning requires the consent to be developed based on collective criticism processes, not on silence or a party line (Forester, 2010, p. 287). The public sphere in which collective criticism processes can be realized and sustained can occur in different forms in today's conditions. According to Bozkurt (2014, p. 519), the ability of networks to offer fast and flexible opportunities to store, distribute and transmit information has caused the idea of network society to gain even more significance in contemporary world. In general, theorists working on network society agree that media and social networks shape the basic structural characteristics of societies and institutions. For example, identifying the difference between the mass society and the network society, Van Dijk (2006, pp. 32-33) suggests that the basic structure of the mass society is the "whole" whereas that of the network society is the "individual". As one of the media where individual opinions and thoughts as well as the collective knowledge are presented, questioned and criticized, Ekşi Sözlük serves to transform the public sphere since it possesses the features of the new media.

Described as a medium or means of communication, the media have undergone many formal changes throughout the history. The change of means of communication continues along with technological developments. Especially "the media" has undergone a profound transformation due to the Internet. Research on the differences between the traditional and new media suggests that digitality, interactivity, hypertextuality and modularity are common characteristics that define the new media (Yengin, 2012, p. 124). The environments that incorporate these features are described as the new media. Van Dijk (2006, pp. 6-7), on the other hand, refers to the most important characteristics of the new media as the integration of telecommunications, data flow and mass communication through a single medium. The new media facilitates the flow of globalized information to the masses and thus has a stronger influence. Thanks to the advanced platforms today, the Internet has become a new area of social relations and a free space of sharing where 
public deliberation takes place through individual-individual, individual-group or group-group interactions and without being limited with boundaries of time, space or any intermediaries, and the new media have the power to guide and transform/change our perspective and thoughts.

Previous research so far has focused on the positive or negative aspects of educational policies and, therefore, innovative projects in the field of education, but research on how a new subject or initiative is perceived and evaluated by the society is limited. For example, Donmuş Kaya and Pepeler (2018) evaluated teacher competencies in using interactive boards in terms of certain variables. Coruk and Tutku (2018) explored teacher concerns towards Fatih Project in Education. Yaşaroğlu (2018) investigated teachers' expectations from and opinions about Fatih project. Kırbaş (2018) examined the opinions of students on using smart boards in Turkish education. Also, Gökmen, Duman and Akgün (2018) investigated the opinions of teachers about Fatih project at schools that were equipped with tablet computers as part of the project. Çiftçi, Taşkaya and Alemdar (2013) studied primary school teachers' opinions on Fatih project. Ekici and Yilmaz (2013) made an evaluation on Fatih project in the context of the project management cycle and argued that the project was not designed according to the project development logic and could not be integrated with the education system. In addition, Pamuk, Çakır, Ergun, Yılmaz and Ayas (2013) evaluated Fatih project based on the views of teachers and students. Similarly, Kuzu, Kurt, Dursun, Güllüpınar and Gültekin (2013) evaluated the implementation process of Fatih project based on student views. Finally, Ayvacı, Bakırcı and Başak (2014) explored the problems arising during the implementation of Fatih project as perceived by administrators, teachers and students. The common point of those studies mentioned above is that they are based on stakeholder opinions and they evaluate the project in the context of the views of administrators, teachers and students. However, considering the scope of Fatih project, it concerns a much wider audience as a public project. The processes related to the project are exceptionally comprehensive. In the light of these points, the primary objective of this study is to explore how FATIH project is perceived and evaluated by the society in the context of Ekşi Sözlük. Thus, this study also aims to discuss the topics presented within the discourses used in Ekşi Sözlük regarding FATIH project and its implementation process, and to determine the chronological phases of the project, the contexts and the ways in which these topics are presented. The entries posted between November 21, 2010 and February 28, 2017 were analyzed under six themes using discourse analysis. Figuring out whether the project is discussed based on subjects such as the project outputs, the educational processes and integration of technology into education or the agenda and policies of a political party and politicians, or other political aspects like the procurement process rather than the implementation process; determining whether research results on the implementation of the project and experiences and reactions of project implementers and beneficiaries are shared in the traditional media and the new media with an objective perspective; identifying the factors that can affect this situation; and, considering that information is reproduced through these media, the findings of the study have important implications for both policy makers and educational practitioners. 


\section{Method}

This study examines the reactions of Ekşi Sözlük authors towards the emergence and implementation of FATIH project, which is introduced as one of the largest national initiatives for the use of technology in education in Turkey and around the world. The purpose of this study is therefore to examine the comments made regarding FATIH project in Ekşi Sözlük in a chronological order, the change and development of the discussions, and Ekşi Sözlük authors' attitudes towards the project. In this context, the foundation of this study rests on the premise that the news in the media or the perspectives existing in the social circles of institutions where the project is implemented has an effect on the perception and interpretation of information, and on reproduction of this information on Ekşi Sözlük, which we can consider a new medium of the media. In order to test this premise, the quantitative and qualitative dimensions of the entries posted in Ekşi Sözlük were examined with respect to the dates when the in-service trainings for the project were introduced, the project processes were announced in the media, the project equipment procurement tender were announced and held, changes to educational policies were made, and the media covered news on the changes in project management and implementation.

Instead of students, teachers or project coordinators, who are directly affected by FATIH project, the sample chosen in this study was the relevant posts in Ekşi Sözlük. There are two reasons for this. The first reason is that speech is constantly contextualized by the presentation of the signs of various conditions or by the restrictions created by social situations in general, and especially by the social relations between the participants as Van Dijk (2006) points out. The second reason is that, given the basic assumption of the critical paradigm that information provided by various media does not include all opinions due to factors such as monopolization of the mass media and general opinion of the society, social sharing platforms, where a person can freely share his or her opinions and ideas in the light of his or her own experiences and the anonymity of the person sharing his or her opinion is protected, offer a more free environment. Presence of freedom of expression in these environments, where alternative ideas are shared, allows seeing the dominant view in the society about the subject in question at the macro- and micro-level. Moreover, with respect to Habermas's concept of public sphere, media like Ekşi Sözlük could be considered as a new form of the public sphere since they allow people to freely deliberate their knowledge, opinions and thoughts with each other, represent opinions outside the official discourse, and seem to have reached a level of interaction that can affect decisions concerning the public.

Launched on February 15, 1999 with the slogan "The Source of Sacred Knowledge", Ekşi Sözlük has been among the most visited sites in Turkey since its inception. According to Alexa (2018) traffic statistics as of August 08, 2018, Ekşi Sözlük ranks 17th among most visited websites in Turkey and 713th in the world. Ekşi Sözlük is basically an interactive information-sharing environment. It is a collaborative hypertext dictionary based on the concept of web sites built on user contribution. The site is in Turkish. In line with the concept of "a dictionary" as the name "Ekşi 
Ayşe AYDIN AKKURT | Hakan YILDIRIM | H. Mustafa DÖNMEZ

Sözlük" translates to English as "Sour Dictionary", registered authors start topics on ideas, concepts, events and dates and express their opinions in the form of 'definitions' and in accordance with a dictionary format. Each opinion posted in the form of a definition under any heading is called "an entry". The users are obliged to comply with rules imposed by Ekşi Sözlük administration (Taşdemir and Çevik, 2013). Ekşi Sözlük is not only a platform where you can find definitions of words, phrases or idioms, but also a social environment where social and political problems on the agenda are discussed. Ekşi Sözlük is a valuable platform where civil discourse is built outside official discourse. In Ekşi Sözlük, one can access a considerable amount of information and a wide variety of resources, references and opinions that are not normally included in official discourse. The most important limitation of Ekşi Sözlük, our study sample, is the difficult and limited process of being a registered author. This limitation, on the other hand, also indicates that commentators on the platform have real personalities and are subject to an auditing mechanism in this sense.

In this study, entries in Ekşi Sözlük about the topic of FATIH project were examined within the framework of discourse analysis proposed by Teun A. Van Dijk. On the other hand, not all dimensions of the method were used since the study sample is a social sharing platform based on personal comments. Discourse analysis can be done in two main levels: micro- and macro-level of analysis. For the macro-level of analysis in this study, we examined how the main concept was perceived and created the themes. For the micro-level of analysis, on the other hand, we examined word choices and causality and rhetoric among sentences.

The object of discourse analysis is texts with written, verbal and non-verbal content (Sözen, 1999). The main purpose of discourse analysis is to make sense or interpretations. Discourse analysis is not focused on people and the number of people, but instead is a qualitative research method conducted with language, language usage patterns and purposes. In discourse analysis, the key criterion that plays a major role in determining sampling approach and representativeness is research objectives/questions (Elliott, 1996). Success of discourse analysis does not depend on sample size because it deals more with specific research questions instead of sample size (Sözen, 1999). Discourse analysis is carried out by analyzing the structure of discourses and ideological infrastructure. This method of research is generally used widely in the field of communication studies carried out in Turkey. Çelik and Ekşi (2008) suggest that examining discourse analysis studies, especially those used in political science and media research, in education and counseling studies in Turkey would provide a deeper and different perspective in these areas. In this study, the method of discourse analysis was used to explore the entries posted under the topic of FATIH project in Ekşi Sözlük.

\section{Results}

Armağan and Deniz (2012, p. 75) argue that the Internet offers more possibilities to individuals than all other means of communication because it facilitates access to information; there are no place-time limitations, opinions can be freely discussed, agendas can be created and others can 
make their voices heard on the internet; and it is beyond the control of political power and, in this sense, it controls the power. Therefore, in terms of perception, interpretation and reproduction of information, this study explored the comments made in Ekşi Sözlük platform, a means of communication and the new media, with regard to FATIH project, a wide-ranging movement implemented as a nationwide project in education. At the time of this study, there were a total of 319 entries under nine topics in Ekşi Sözlük that included the phrase "FATIH Project". The following are these topics:

- fatih project (307)

- fatih project e-book reader distribution (1)

- fatih project information line (3)

- fatih project contract award to telpa (1)

- vestel's exclusion from fatih project (3)

- allegations of corruption for justice and development party in fatih project (1)

- remote access program scandal in fatih project (1)

- diablo iii distribution within fatih project (1)

- the promotional video of fatih project (1)

In this study, 307 entries posted between November 21, 2010 and February 28, 2017 under the topic "fatih project" regarding FATIH project and the implementation process were analyzed in accordance with the purpose and scope of the study and by using the method of discourse analysis.

For the analysis of the comments in the entries, the aspect of the project each comment was made on, the sources of information, and the expressions used in the comments were categorized. Semantic and linguistic errors in the comments as well as unclear and ambiguous expressions are among the limitations of this study. Postman (2004, p. 63) suggests that written words promote what Walter Ong calls the "analytic management of knowledge" and involving written words is only possible by following a line of thought, and this demands significant skills of classifying, inference-making and reasoning. Van Dijk (1997, p. 29), on the other hand, points out that discourse analysis deals with naturally occurring text (written) and talk (verbal), and these written and verbal discourses are real data because they do not compromise on their reality and nature and do not pass through any addition or sterilization. In this study, the data set consisted of discourses as they naturally occurred in Ekşi Sözlük.

In the macro dimension of discourse analysis, the way in which the main concept was deliberated was examined and the themes were created. Firstly, the contexts in which FATIH project was discussed as the main concept and the subjects that emerged in the comments were examined, and then six themes were identified in the entries. Using the NVivo software, all the relevant en- 
tries were listed and analyzed in terms of discourses and especially platform-specific language. Firstly, the contexts in which the main concept of FATIH project was discussed and the prominent subjects embedded in the comments were examined, and six themes were determined in the entries. While determining the themes, the researchers examined previous studies on Fatih project and tried to include all the dimensions in the analysis (Akgün, Yılmaz and Seferoğlu, 2011; Ekici and Yılmaz, 2013; Yolcu and Bayram, 2016; Öçal and Şimşek, 2017). The themes identified are educational dimension, economic dimension, project design dimension, political/ideological dimension, technological dimension and innovation dimension. The discourses in the entries were classified under the theme headings in negative and positive attitudes, and the data classified this way were presented in Table 1.

Table 1. Negative and Positive Discourses Embedded in Ekşi Sözlük Entries about Fatih Project According to Themes

\begin{tabular}{lcc}
\hline \hline Theme & Positive & Negative \\
\hline Educational Dimension & 7 & 61 \\
Economic Dimension & 2 & 50 \\
Project Design Dimension & 0 & 75 \\
Political/Ideological Dimension & 5 & 72 \\
Technological Dimension & 13 & 67 \\
Innovation Dimension & 13 & 7 \\
Total & 40 & 332 \\
\hline
\end{tabular}

The first theme in terms of how the main concept was deliberated includes the entries categorized under the educational dimension. This category included entries questioning teacher competencies and curriculum content, those claiming that different priority projects should be included in the field of education, those advocating the adverse effects of technology in educational sense, those suggesting that the project would provide the necessary innovations for education, and those arguing that the implementation of the project would be useless/harmful in educational sense. In the context of this theme, many Ekşi Sözlük authors used the words 'education', 'project', 'tablet', 'teacher', 'course' and 'course book' concerning the educational dimension of FATIH project. The need to increase the quality of teachers was one of the most emphasized issues, as the suggestion that use of technology could not lead to an improvement in the expected level of quality in education (e.g. equal opportunities in education, increase in information literacy and so on). However, apart from these negative opinions, some authors had positive opinions about the project and they stated that technological infrastructure support provided individually by parents until then would now be granted by the state, the project would make a huge differ- 
ence even if it could not satisfy the expectations at the desired level, the quality of education would be improved and existence of many deficiencies in the field of education should not prevent the implementation of this "revolutionary" project. Cumulative progress was observed under this theme, in which the majority of the opinions were negative, and authors first read the entries preceding theirs and then came up with new theses and antithesis for them. Authors with positive discourses responded to negative opinions using a critical writing style by writing, for example, "despite those whining here, it is a project that has worked pretty well ${ }^{1 \text { ". }}$ Authors with negative discourses shared the experiences of their own or their friends by writing, for example, " $\mathrm{i}$ have a friend who is a computer teacher, she is a high school teacher in the heart of ankara, she was in diyarbakır before. do you know what she complains about the most? ${ }^{2 \prime}$, or they compared FATIH project with the previous one by stating, "we can see even the simplest example in the dyned program on which a lot money was invested for years to be used in english education."

The second theme in terms of how the main concept dealt with the economic dimension. This theme included entries emphasizing the irregularities and corruption allegations related to contracts, entries arguing that the use of the project budget in other areas would be more efficient, entries claiming that the project budget paid by taxpayers was not spent efficiently and appropriately, entries complaining that the project purchases would be/had been made from foreign companies, and entries claiming that foreign companies would benefit from the project purchases. The issue discussed most in the economic dimension was contracts and equipment procurement processes. The first public procurement tender was held on December 12, 2011; the second one was held on October 9, 2012; and the third and the largest one was held on June 24, 2013. A chronological analysis show that the number of entries posted on the dates of the public procurement tenders was independent from these dates. Out of the entries analyzed, two included positive comments while the remaining 50 included negative comments. One of the authors with a positive opinion about the projects wrote, "the project whose procurement tender should not be considered a big deal... if the quality of education will be improved, $\mathrm{i}$ am in favor of this project; this is my opinion" ". There were also some authors who stated their concerns about the project and agreed with other doubts but still had positive opinions about the project because it was a prerequisite for bidders to make R\&D and manufacturing in Turkey ${ }^{5}$. The number of negative comments increased in chronological order, and these comments were generally made up of entries containing expressions of disappointment about the project. The entries with negative discourse under this theme included comments such as, "i wish a turkish company would be

${ }^{1}$ 02.06.2016 gaileli ( https://eksisozluk.com/entry/60907449)

2 21.11.2010 etxeberria (https://eksisozluk.com/entry/20934873)

${ }^{3}$ 22.11.2010 buldum (https://eksisozluk.com/entry/20951200)

${ }^{4}$ 23.11.2010 underzero (https://eksisozluk.com/entry/20953236)

${ }^{5}$ 26.07.2013 fatman (https://eksisozluk.com/entry/35502161) 
awarded the contract, but I also wish that company would carry out all $r \& d$ and implementation in this country by making the necessary investment. otherwise, we cannot go beyond another urban legend in the late $80 \mathrm{~s}$ 'we are producing $\mathrm{f} 16 \mathrm{~s}$, dude ${ }^{6}$ ", "the project where rotten smells coming

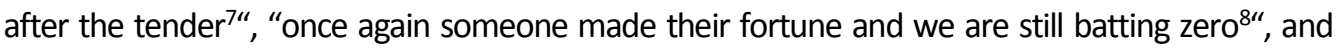
"the project is just another example of how the resources of our country are wasted" ". Comments like these contain suggestions that procurement tenders are held improperly and the government favors certain companies. In general, there were not any sources cited for the negative comments, or the authors posted their comments on the information obtained from TV prime time news and newspapers. As Van Dijk (2005, p. 325) states, people use a variety of discourses, including personal narratives, and the information derived from them to make up or change their minds. Considering Ekşi Sözlük authors' skills for using the Internet, means of mainstream media seem to be still very influential in informing the society. The comments in the entries with negative comments in qualitative terms contain superficial information about those who were awarded the tenders.

The third theme includes the entries categorized under the project design dimension. This theme included entries criticizing the prejudiced attitudes against the project, those suggesting that the project is not well designed, those suggesting that the project should be approached cautiously, those predicting the negative consequences of missed elements in project design, and those making comments on different phases of the project. Authors with positive opinions about the design of FATIH project used expressions like "this is a revolutionary project ${ }^{10 ", ~ " . . . i t ~ w i l l ~ m a k e ~}$ the future look more hopeful ${ }^{111 ", ~ " e v e n ~ t h e ~ p o s s i b i l i t y ~ o f ~ r e a l i z a t i o n ~ o f ~ t h i s ~ p r o j e c t ~ e x c i t e s ~ m e ~ a s ~ a ~}$ teacher ${ }^{12 "}$ ", and "the project that makes others jealous ${ }^{13 "}$. In one of the entries with positive statements, the author was assured there was incredible effort to realize the project and told about his or her own experience by writing, "i can say on behalf my team that the infrastructure is prepared with great care and strict supervision ${ }^{14 \prime}$. In the entries with negative expressions, the criticism is particularly towards the project name. In line with the peculiar jargon of Ekşi Sözlük,

\footnotetext{
${ }^{6}$ 11.11.2013 loosey (https://eksisozluk.com/entry/38230368)

${ }^{7}$ 12.11.2013 turk eli (https://eksisozluk.com/entry/38264766)

8 14.01.2015 travenian (https://eksisozluk.com/entry/48418801)

${ }^{9}$ 28.02.2017 nick ass (https://eksisozluk.com/entry/66562930)

${ }^{10}$ 08.12.2010 detroitli kizil (https://eksisozluk.com/entry/21094911), 10.02.2012 hubaku (https://eksisozluk.com/entry/27352610)

11 14.12.2011 hakansari (https://eksisozluk.com/entry/26543610)

12 08.02.2012 smete (https://eksisozluk.com/entry/27337196)

${ }^{13}$ 18.07.2012 mvltyldz (https://eksisozluk.com/entry/29451136)

${ }^{14}$ 18.09.2015 pisikletadam (https://eksisozluk.com/entry/54897003)
} 


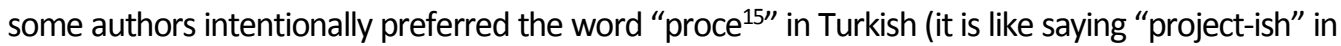
English instead of "project") to deprecate the project or to show that it is a bad project. Other comments on the poor design of the project were presented in terms of personal experience and knowledge. Other negative entries include comments like, "the project in which everyone is obsessed with tablets and their specifications. however, there is a very important problem that will cause this project to be a stillbirth: teachers of information technology who ministry national education treats like stepchildren... ${ }^{16 "}$, "the project which nobody can explain the pedagogical value and contribution of. as a project that was launched and implemented in a rush without examining other similar projects around the world and without consulting with stakeholders such as teachers and school administrators and experts of the subject, this initiative is likely to cause some dangers, let alone bringing benefits... ${ }^{17 ", ~ " j u s t ~ a n o t h e r ~ a k p ~[J u s t i c e ~ a n d ~ D e v e l o p m e n t ~ P a r t y] ~ p r o j e c t ~ t h a t ~ w a s ~}$ forced into our lives with the mentality of 'this is what I did, so deal with it' without even being discussed by the actual stakeholders involved, educators, and without thoroughly thinking about the advantages and disadvantages ${ }^{18}$ ", "the project whose smart I tested for some time in a high school today. unfortunately, like every project of the government this is another example of carelessness and negligence. this causes the project to be fallacious from the beginning... ${ }^{19}$ ", "the project that has been sloppily and cautiously pushed into our educational system, which already has countless deficiencies especially such as qualified human power and a scientific curriculum ${ }^{20 \prime \prime}$. Analysis of these entries show that there are few entries focusing on the project design and implementation processes in a way independent from a political and ideological perspective, and that the authors post their entries with discourses in line with their previous attitudes, beliefs and knowledge.

\footnotetext{
${ }^{15} 23.11 .2010$ tavlada iki (https://eksisozluk.com/entry/20960540), 16.09.2011 zoltan9 07.02.2012 camelf (https://eksisozluk.com/entry/27315134), 07.02.2012 terrordrone birgunolursun (https://eksisozluk.com/entry/61027245)

16 19.08.2011 terrordrone (https://eksisozluk.com/entry/25019766)

17 07.02.2012 theperfectman (https://eksisozluk.com/entry/27318107)

18 07.02.2012 buenaventura (https://eksisozluk.com/entry/27320391)

${ }^{19}$ 30.09.2012 pyloge (https://eksisozluk.com/entry/30396608)

${ }^{20}$ 28.02.2017 nick ass (https://eksisozluk.com/entry/66562930)
} (https://eksisozluk.com/entry/25391044), 06.02.2012 thejoygamer (https://eksisozluk.com/entry/27309627), (https://eksisozluk.com/entry/27316062), 07.02.2012 dirk pitt (https://eksisozluk.com/entry/27319499), 09.06.2016 


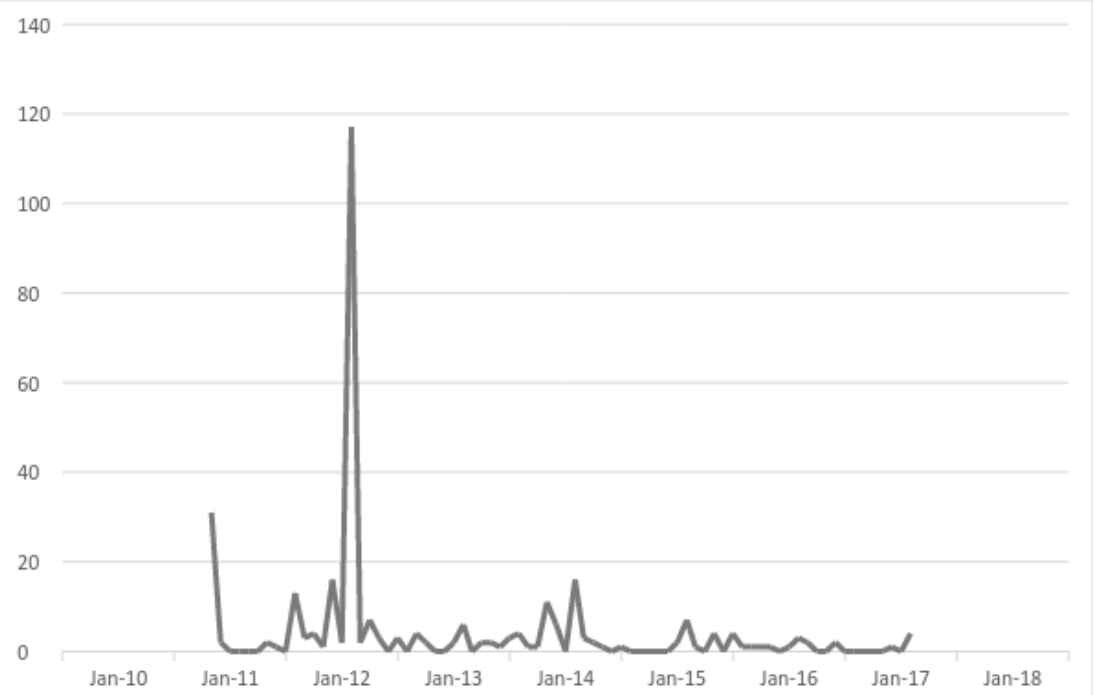

Figure 2. Number of Entries Under the Topic "FATIH Project" in Ekşi Sözlük by Month

The fourth theme in terms of how the main concept was deliberated includes the entries categorized under the political/ideological dimension. This theme included entries suggesting that the name preference of the project is an ideological one, those arguing that the project has a political and ideological structure, and those either criticizing or supporting and appreciating the current government based on the project. Analysis of the entries under the political/ideological dimension show that the project is generally thought to belong to the current political party, and that the positive or negative comments are mostly made based on this premise. The largest number of entries about the project was in February 2012. The inauguration ceremony of the FATIH Project by Prime Minister Recep Tayyip Erdogan was on February 6, 2012, which is one of the important dates for the project (Figure 2). The increase in the number of entries on the day the prime minister attended the promotion of the project as a political figure shows that the project is perceived and interpreted within an ideological context. An author associated FATIH project with the government's previous projects and attitudes by writing, "the project that I watched on show tv news along with our prime minister's speech. Our president said, "we are disposing the age of blackboard and opening a new era. farewell to the old and salute the new... etc. etc. ... the usual enthusing talks ${ }^{21 "}$ On the other hand, the critics of the project was described as government opposition. One of the authors, for example, wrote, "a revolutionary project. ignore those cheap government opponents ... the government is very successful in education. the ridiculous and stale

${ }^{21}$ 07.02.2012 gokahnsIm (https://eksisozluk.com/entry/27315778) 
curriculum is over now. textbooks were distributed free of charge. if this project is implemented, it will increase the level of education. this project was put into action by the district governor years ago in gürün, a small town in sivas, and even top scorers in sbs exam were from this town. i mean some will make cheap opposition and some will act and work ${ }^{22 \prime}$. Both the entries against the project and those in favor of it were in fact posted with political and ideological discourses by criticizing the opposition or the government the instead of focusing on the project. Nevertheless, developments such as procurement tenders did not have such an effect.

The fifth theme in terms of how the main concept was deliberated includes the entries categorized under the technological dimension. This theme included entries about the technology and infrastructure of FATIH project. Among all the entries about the project, this group contained the highest number entries with comments posted with a technological reference. Having a negative attitude in general, authors were convinced that the equipment to be procured with the project cannot be used in existing schools and they posted the following entries: "the painful thing is that in 2010 we still have not been able to solve problems with the school infrastructure such as buildings classes, toilets... ${ }^{23 \text { " }}$ and "a positive project in terms of the ability of students who are chilly in school with/without heating system to warm their hands on heated tablets ${ }^{24 \prime}$ to point to the fact that the physical infrastructure of schools does not meet basic needs; "how many teachers can use tablet computers efficiently in class with students is a mystery ${ }^{25 \prime}$ to argue that technology knowledge of educators will be insufficient to reach the project goals; and "it is a waste of money for paying for these tablets as long as we do not have a sector that can produce appropriate software for them... ${ }^{26 \prime \prime}$ to criticize the lack of technology production in Turkey. The positive entries, on the other hand, suggested that considering FATIH project as a tablet PC project is wrong and integration of technological tools into education would have positive outcomes. For example, authors posted, "I wonder why people make a big fuss over microsoft event... ${ }^{27 "}$ to suggest that it is unnecessary to dwell on the use of foreign products, and "a project in which technical specifications have been changed in order to promote using pardus instead of microsoft products. this change will be very useful in the development of free software and also in breaking microsoft's monopo$\mathrm{ly}^{28 \prime \prime}$ to express their pleasure to see support for open source software.

22 08.12.2010 detroitli kizil (https://eksisozluk.com/entry/21094911)

${ }^{23} 21.11 .2010$ post pozitivist (https://eksisozluk.com/entry/18091943)

${ }^{24}$ 07.02.2012 ironik maymun (https://eksisozluk.com/entry/27317808)

25 07.02.2012 vagus579 (https://eksisozluk.com/entry/27315923)

${ }^{26} 19.08 .2011$ silmaril (https://eksisozluk.com/entry/25018155)

${ }_{27} 22.11 .2010$ allinone (https://eksisozluk.com/entry/20949956)

28 19.08.2011 dbg (https://eksisozluk.com/entry/25023409) 
The sixth theme in terms of how the main concept was deliberated includes the entries categorized under the innovation dimension. This theme included entries making suggestions for the success of the project in achieving its objectives, entries arguing that the project will lead the way in innovative approaches that have long been needed in the traditional education system, and entries criticizing people's negative approach to innovation through the project. The innovation theme is the only one where positive opinions about the project are more than negative ones. In these positive entries, while the excitement of the promised changes is emphasized, the opposition to it is also criticized. For example, authors posted, "a project that is the precursor of the change in educational materials used almost unchanged from the early years of the republic, perhaps from the pre-republic period to the present day... ${ }^{29 "}$ and "when i read the entries posted, $\mathrm{i}$ can now better see bullshit like why the national automobile project 'devrim' was not implemented in this country, how the aircraft factories were shut down, how the village institutes were closed, and so on ${ }^{30 \prime \prime}$.

Entries that included only numerical data, that were impossible to understand, that did not contain any comments, or that consisted of links to different news sites were categorized under the theme heading "other", and these entries were not included or analyzed in the comments but presented as a part of percentile data. The distribution of entries/comments categorized under the themes is shown in Table 2.

Table 2. Numerical Values and Percentages of Entries Posted in Ekşi Sözlük About FATIH Project with Respect to the Research Themes

\begin{tabular}{lcc}
\hline \hline Theme & Frequency & $\%$ \\
\hline Technology & 89 & 20 \\
Politics / Ideology & 82 & 19 \\
Project Design & 77 & 18 \\
Education & 74 & 17 \\
Economy & 62 & 14 \\
Other & 29 & 7 \\
Innovation & 24 & 5 \\
\hline
\end{tabular}

${ }^{29} 22.11 .2010$ hingiryano (https://eksisozluk.com/entry/20629181)

30 14.12.2011 hakansari (https://eksisozluk.com/entry/26543610) 


\section{Discussion, Conclusion and Suggestions}

FATIH project has been a trending topic in Turkey since its launch and has been a concern not only to educators in the country but also to the majority of the public as it involves various components and stakeholders. This study is aimed to analyze how FATIH project is presented Ekşi Sözlük under the premise that, in the presence of a political/ideological dimension, despite the presence of many dimensions of the phenomenon in question, the main elements can be ignored in the evaluation of the project purpose and process, and information obtained through prejudice, assumptions and mainstream media can be manipulative. News presented in the mainstream media or people that make comments about a project in the media can be prejudiced and misleading in their positive or negative approach to the project. The Internet, which is considered to be the new media as an alternative and a new public sphere, offers opportunities for people to discuss their thoughts more freely than other means of the media. Apart from ensuring freedom of expression by protecting anonymity without being censored, the Internet can occasionally serve as a platform for provocation, manipulation, or hate speech. While ideas shared on the Internet create a unique environment in terms of the appearance of public thoughts and the formation of the public sphere, the Internet emerges as an environment that needs to be examined in depth to see the whole picture as it contains speculative and manipulative elements.

In this study, we analyzed all the entries posted in Ekşi Sözlük about FATiH project for 2291 days ( 6 years, 3 months and 7 days) between November 21, 2010 and February 28, 2017 concerning the launch, infrastructure preparations, procurement tenders, implementation and outcomes of the project finalization processes.

A total of 319 entries under nine topics about FATIH project were posted in Ekşi Sözlük. In general, topics that point to a particular situation about the project or those implying an opposing or justifying attitude towards it never became trending among Ekşi Sözlük authors. In fact, there were only 12 entries under such topics. However, the inclusive topic "fatih project" contained the highest number of entries about the project.

Among the themes embedded in 307 entries poster under the topic "fatih project" were those entries arguing that FATIH project will not meet the educational priorities in Turkey's current education system, entries suggesting that the project budget should be questioned regarding the transfer of resources due to its amount, entries written in the context of project design and implementation processes, entries commenting on the project within a political/ideological context, entries concerning the technologies and infrastructure used within the scope of the project, and entries about the innovative structure of the project. Entries sometimes contained statements about multiple themes. Within the themes identified in 307 entries, there were 332 negative expressions and 40 positive expressions about the project. As a result of the discourse analysis of the entries, it was determined that at macro level the project was mostly criticized in terms of project design dimension and political/ideological dimension, and the entries with positive expressions were related to the themes of technology and innovation. 
This study also established that information sources of people are of great importance in the process of acquiring, structuring, reproducing, and distributing information. Examination of the entries in Ekşi Sözlük and the resources cited shows that there are not any platforms in which all aspects of FATIH project process are examined and all the data related to the project are presented transparently. Moreover, comments such as, "There seems to be a leadership problem and poor public relations performance (Akgül, 2013)" confirms the inadequacy of publicity and public relations activities.

Comments in the entries about the project were generally based on informal sources of information, such as news about FATIH project in popular newspapers, news on online news websites, personal experiences, and indirect information shared by friends and relatives. In addition to this, screenshots of presentations and sources such as speech transcripts are also cited as sources to justify comments. It was determined that both the number entries posted in Ekşi Sözlük about FATIH project and the interaction about authors increased particularly on the dates when official resources made announcements about the project. It could therefore be suggested that all the project components should be accessible on a variety of platforms so that such a large-scale project can be presented properly and understood accurately by all the stakeholders and the public.

The discourses in the posts also showed that detailed and transparent construction of the economic dimensions of a project is important in terms of social acceptance and that citizens feel uncomfortable when there is not sufficient data available in this regard. It was therefore determined that prioritizing the element of transparency in the project design process affects the sustainability and acceptance of a project. When individuals cannot access information adequately, they tend to construct their discourses based on their previous attitudes, beliefs and experiences.

We also observed that the personal discourses of politicians presented in the mainstream media have more influence on the formation of discourses in Ekşi Sözlük than concrete facts such as tenders, trainings and workshops related to the project management process. Developments and projects developed in the field of education are generally associated with the existing government and, therefore, with politicians. Expressions related to this are clearly seen in the discourses in Ekşi Sözlük. Our results showed that FATIH project is perceived as a project of the political party having the majority of the votes in the government in line with the statements made by the information sources. Therefore, we could suggest that carrying out promotional activities related to a project effectively to include all the processes involved and using common resources of information can improve how the project is perceived and increase the extent to which it is understood.

The results also showed that, in none of the entries posted in Ekşi Sözlük about FATIH project, such a large-scale project with many stakeholders was deliberated in terms of possible outcomes, infrastructure, implementation process, training of trainers, introduction and contemporary education practices in comparison with other similar projects around the world. Therefore, it was 
determined that the FATIH project, which is basically an education project, is generally evaluated in economic and political context. Perception of the project in this context hinders the project to be assessed in terms of educational outcomes, which is actually the main basis for the project. Identifying the presence of this situation in a public sphere like Ekşi Sözlük that reflects social perceptions through individual discourses is particularly significant in terms of observing the level of awareness of future educational studies and their results.

The themes concerning economy, technology, infrastructure and politics embedded in relevant entries show that the educational dimension of the project has not received the attention it deserves. The project has been discussed in terms of technological, political/ideological and project design rather than the educational dimension. We observed that Ekşi Sözlük authors constructed their discourses with criteria such as political, economic and technological infrastructure rather than criteria such as educational processes, education integration of the technology and its global results. This shows the level of knowledge and awareness in Turkey about FATIH project, which is regarded as one of the world's most comprehensive and largest educational initiatives.

Finally, although the five fundamental principles of FATIH project are accessibility, efficiency, equality of opportunity, measurability and quality, these principles were not taken as a criterion in the entries posted in Ekşi Sözlük about the project. While these entries did not include any discourse related to accessibility and measurability, they addressed equality of opportunity, productivity and quality in relation to the project design processes. This results shows that the authors ignored the concepts of accessibility and measurability, which are extremely important in the field of education. Considering the importance of accessibility of information resources and presentation of information through transparent and widespread sources of information, it is recommended that future research explore stakeholder participation in future projects.

\section{References}

Akgül, M. (2013). FATIH Project: Problems, Risks and Concerns [FATIH Projesi: Sorunlar, Riskler ve Endişeler]. http://dergi.bmo.org.tr/egitim/FATIH-projesi-sorunlar-riskler-ve-endiseler

Accessed on May 5, 2017.

Akgün, E., Yılmaz, E.O., and Seferoğlu, S.S. (2011). Vision 2023 strategy document and the movement to increase opportunities and improve technology (FATIH) project: A comparative review [Vizyon 2023 strateji belgesi ve fırsatları artırma ve teknolojiyi iyileştirme hareketi (FATiH) projesi: Karşılaştırmalı bir inceleme]. Akademik Bilişim, 2(4), 115-122.

Atabek, Ü. (2005). New Communication Technologies and Media [Yeni Iletişim Teknolojileri ve Medya]. İstanbul: IPS illetişim Vakfı Yayınları

Armağan, A. and Deniz, Ş. (2012). Representation of child abuse on social networking platforms: presentation of children staying in Pozanti juvenile hall on ekşi sözlük. The Journal of Academic Social Science Studies, 5(7). 
Alexa (2018) http://www.alexa.com/siteinfo/eksisozluk.com, Web, accessed in February 15, 2018.

Ayvacı, H.Ş., Bakırcı, H., and Başak, M.H. (2014). The evaluation of problems emerging during the implementation process of fatih project by administrators, teachers and students. YYU J. Educ. Faculty, 9, 21-47.

Bozkurt, A. (2014). Network society and knowledge. Türk Kütüphaneciliği, 28(4), 510-525.

Coruk, A., and Tutkun, T. (2018). Teacher Concerns towards the Fatih Project in Education. Turkish Online Journal of Educational Technology-TOJET, 17(4), 42-53.

Çelik, H. and Ekşi, H. (2008). Discourse analysis. Marmara Üniversitesi Eğitim Bilimleri Dergisi, (27), 99-117.

Çiftçi, S., Musa Taşkaya, S., and Alemdar, M. (2013). The opinions of classroom teachers about Fatih Project. Ilkogretim Online, 12(1).

Demir, F. (2011). The role of negotiation in public policy making process and the democratization of public policy process [Kamu politikası oluşturma sürecinde "müzakere" nin rolü ve kamu politikası sürecinin demokratikleştirilmesi], (Ed. Alican Kaptı) Kamu Politika Süreci. Seçkin, Ankara.

Doğan, D., Çınar, M. and Seferoğlu, S.S. (2016). “One Laptop per Child” projects and FATIH project: A comparative examination. SDU International Journal of Educational Studies, 3(1), 126.

Donmuş Kaya, V., \& Pepeler, E. (2018). An investigation of some variables in terms of teacher's competencies about using interactive whiteboard. Firat University Journal of Social Sciences, 28(2).

Dursun, Ö.Ö., Kuzu, A., Kurt, A.A., Güllüpınar, F., and Gültekin, M. (2013). Views of school administrators' on Fatih projects pilot implementation process. Trakya University Journal of Education, 3(1), 100-113.

Ekici, S. and Yılmaz, B. (2013). An evaluation on Fatih project. Türk Kütüphaneciliği, 27(2), 317-339.

Elliott, R. (1996). Discourse analysis: exploring action, function and conflict in social texts. Marketing Intelligence \& Planning. 14, 6, 65.

García-Peñalvo, F.J. (2016, September). A brief introduction to TACCLE 3-coding European project. In Computers in Education (SIIE), 2016 International Symposium on (pp. 1-4). IEEE.

Gökmen, Ö.F., Duman, İ., and Akgün, Ö.E. (2018). Teachers' Views about the Use of Tablet Computers Distributed in Schools as Part of the Fatih Project. Malaysian Online Journal of Educational Technology, 6(2), 21-37. 
Friedland, L.A., Hove, T., \& Rojas, H., (2006). The Networked Public Sphere. Javnost-The Public/European Institute for Communication \& Culture, 13(4), 5-26.

Forester, J. (2010). Theories of Mass Communication [Kitle Iletişim Kuramları] (Ed. Mutlu). Ankara: Ütopya.

Information Society Strategy and Action Plan (2006-2010), http://www.edevlet.gov.tr/2015/10/13/2006-2010-bilgi-toplumu-stratejisi-ve-eylem-plani/ Web, accessed on April 12, 2018.

Kirbas, A. (2018). Student Views on Using Smart Boards in Turkish Education. Universal Journal of Educational Research, 6(5), 1040-1049.

Ministry of Development Information Society Department. (2015, March). 2015 - 2018 Information Society Strategy and Action Plan. Information Society Strategy Project and Participation Portal: http://www.bilgitoplumustratejisi.org/tr/doc/8a9481984680deca014bea4232490005 Website, accessed on November 4, 2017.

Ministry of Development (2013). Tenth Development Plan (2014-2018) http://www.kalkinma.gov.tr/Pages/KalkinmaPlanlari.aspx accessed in May 5, 2017.

Ministry of Education, (2015) 2015-2019 Strategic Plan, MNE Strategy Development Unit, Ankara. (T. C. Ministry of Development Information Society Department, 2015)

Ministry of Education (2017) About FATIH Project in Education. http://FATIHprojesi.meb.gov.tr/proje-hakkinda/ accessed on May 5, 2017.

Öçal, M.F. and Şimşek, M. (2017). Mathematics teacher candidates' views on FATIH project and the use of technology in mathematics education. Turkish Online Journal of Qualitative Inquiry, 8(1), 91-121.

Pamuk, S., Cakir, R., Ergun, M., Yilmaz, H.B., and Ayas, C. (2013). The use of tablet PC and interactive board from the perspectives of teachers and students: Evaluation of the FATiH Project. Educational Sciences: Theory and Practice, 13(3), 1815-1822.

Postman, N. (2004). Amusing Ourselves to Death: Public Discourse in the Age of Show Business. Penguin.

Sözen, E. (1999). Discourse: uncertainty, exchange, knowledge, power and reflexivity [Söylem: belirsizlik, mübadele, bilgi, güç ve refleksivite]. İstanbul: Paradigma.

Taşdemir, B. and Çevik, R. (2013). Dominant Design and Sourtimes Dictionary: Understanding the Transformation of Internet. Iletişim Kuram ve Araştırma Dergisi, 1(37). 
Timisi, N. (2003). New Communication Technologies and Democracy [Yeni Iletişim Teknolojileri ve Demokrasi]. Ankara: Dost.

Turkish Statistical Institute (2016), "Youth in Statistics" http://www.tuik.gov.tr/PreHaberBultenleri.do?id=24648 accessed in May 12, 2017.

Uçkan, Ö. (2003). E-government, e-democracy and Turkey [E-Devlet, E-Demokrasi ve Türkiye]. İstanbul: Literatür.

Van Dijk, T. (Ed.) (1997). Discourse as structure and process (Vol. 1). London: Sage.

Van Dijk, T. (2005). Söylemin yapıları ve iktidarın yapıları. Der: Mehmet Küçük, Medya İktidar İdeoloji, Ankara: Bilim ve Sanat

Van Dijk, T. (2006). The Network Society: Social Aspects Of New Media. London: Sage Publications.

Volkmer, I. (2003). The Global Network Society and Global PublicSphere, Society for International Development: Thematic Section, 46(1), 9-16.

Yaşaroğlu, C. (2018). The investigation of teachers' expectations and recommendations on Fatih project. Journal of Social Sciences Institute, 8(15), 147-159

Yengin, D. (2012). Critical Review of New Media, New Media and ... [Yeni Medyaya Eleştirel Bakış, Yeni Medya ve...], İstanbul: Anahtar Kitaplar.

Yolcu, H., and Bayram, A. (2016). Usage of technology in education: a critical view on the Fatih project. Abant İzzet Baysal Üniversitesi Eğitim Fakültesi Dergisi, 16(4), 2111-2143.

Yükselbaba, Ü. (2008). Public sphere models and context of these models. İstanbul Üniversitesi Hukuk Fakültesi Mecmuası, 66(2), 227-271. 